\title{
Online learning models for junior high school students in the era of the COVID-19 pandemic
}

\section{Model pembelajaran daring pada siswa sekolah lanjut tingkat pertama di era pandemi COVID-19}

\author{
Fatchur Rohman, Yanto Yanto, M. Lutfi Hidayatullah, Riska Roisatul Ajizah, Endah Junita Sari \\ Departemen Akuntansi, Fakultas Ekonomi dan Bisnis, Universitas Islam Nahdlatul Ulama \\ Jl. Kauman, Jepara, 59451, Indonesia
}

\begin{abstract}
ARTICLE INFO
Received: 2021-04-17

Revised: 2021-06-24

Accepted: 2021-08-06

Keywords:

Learning Media, COVID-19, Innovative, Interactive, Web-based

\section{ABSTRACT}

In this era of the COVID-19 pandemic, many students experience obstacles in their learning process, especially in implementing online learning models. The purpose of the community service program is to apply online learning models and media that can be used in learning in the era of the COVID-19 pandemic. This program is intended for teachers and students at MTS SA PP Roudlotut Tholibin in Bandungharjo Village, Donorojo District, Jepara Regency. The implementation stages of the program include the development of learning tools and media, the application and process of making learning media, the use of website-based learning applications, and mentoring and application of web-based learning applications. The results of the community service program are guidelines for using webbased learning applications and innovative learning media. The results of the program show that the application of online learning models with innovative media can improve teacher performance and student understanding. Teachers can use creative media properly. Students' understanding has increased in learning during the COVID-19 pandemic.
\end{abstract}

(C)2021 Published by University of Merdeka Malang. This is an open access article distributed under the CC BY-SA 4.0 license (https://creativecommons.org/licenses/by-sa/4.0/)

How to cite: Rohman, F., Yanto, Y., Hidayatullah, M. L., Ajizah, R. R., \& Sari, E. J. (2021). Online learning models for junior high school students in the era of the COVID-19 pandemic. Abdimas: Jurnal Pengabdian Masyarakat Universitas Merdeka Malang, 6(4), 478-490. https://doi.org/10.26905/abdimas.v6i4.5709

\section{PENDAHULUAN}

Munculnya wabah Coronavirus 2019 (COVID-19) pada Maret 2020 ditandai dengan pengumuman pemerintah terkait kasus pertama pasien Coronavirus 2019 (COVID-19) yang terjadi pada Maret 2020, Indonesia mulai dihadapkan pada pandemi. Dengan munculnya Coronavirus tersebut maka hampir seluruh sektor kehidupan di Indonesia terdampak, tidak terkecuali di sektor pendidikan. Penularan wabah Coronavirus 2019 di dunia begitu pesat termasuk di Indonesia dan telah menyebar ke hampir semua negara termasuk Indonesia, sehingga Badan Kesehatan Dunia (WHO) menjadikan wabah ini menjadi pandemi global pada 11 Maret 2020. Di Indonesia pemerintah melalui Kementerian Pendidikan dan 
Kebudayaan (Kemdikbud) telah menerapkan kebijakan pembelajaran dari rumah (BDR), khususnya bagi lembaga satuan pendidikan yang berada di zona kuning, oranye, dan merah. Hal tersebut berdasarkan Keputusan Bersama Menteri Pendidikan dan Kebudayaan, Menteri Agama, Menteri Kesehatan dan Menteri Dalam Negeri tentang Pedoman Pelaksanaan Pembelajaran Tahun Ajaran 2020/2021 saat COVID19 (Kemdikbud, 2020). Bagi institusi satuan pendidikan yang berada di zona hijau dapat melaksanakan pembelajaran tatap muka (offline) dengan tetap memperhatikan protokol Kesehatan yang cukup ketat.

Kabupaten Jepara sendiri memiliki 1.145 satuan pendidikan yang tersebar di 16 Kecamatan mulai dari SD sederajat, SMP sederajat, SMA sederajat dan SMK (Data Referensi Kemendikbud, 2020). Adapun data satuan pendidikan di Kabupaten Jepara disajikan pada Gambar 1.

\begin{tabular}{|c|c|c|c|c|c|c|c|c|c|c|c|c|c|c|}
\hline \multirow{2}{*}{ No: } & \multirow{2}{*}{ KECAMATAN } & \multicolumn{3}{|c|}{ So Sederajat } & \multicolumn{3}{|c|}{ SMP Sederajp: } & \multicolumn{3}{|c|}{ SMa Sestarsigt } & \multicolumn{3}{|c|}{ SMK } & \multirow{2}{*}{ TOTAL } \\
\hline & & $\mathbf{N}$ & $\mathrm{s}$ & $J M L$ & $\mathbf{N}$ & $s$ & $M$ & $N$ & s & $\mathrm{M} M$ & $\mathbf{N}$ & s & $\mathrm{M}$ & \\
\hline & TOTAL & 574 & 219 & 793 & 41 & 171 & 212 & 12 & 78 & 90 & 9 & 41 & so & 1,145 \\
\hline 1 & Kece. Kedung & 34 & 17 & 51 & 3 & 21 & 24 & 0 & 12 & 12 & 1 & 1 & 2 & 89 \\
\hline 2 & Kec. Pecanguan & 39 & 7 & 46 & 2 & 8 & 10 & 1 & 4 & 5 & 0 & 2 & 2 & 63 \\
\hline 3 & Kec. Welahan & 46 & 5 & 51 & 3 & 7 & 10 & 1 & 3 & 4 & 0 & 1 & 1 & 66 \\
\hline 4 & Kec. Mayong & 41 & 17 & 58 & 2 & 13 & 15 & 1 & 6 & 7 & 0 & 6 & 6 & 86 \\
\hline 5 & Kec. Nalumsani & 39 & 13 & 52 & 2 & 9 & 11 & 1 & 4 & 5 & 0 & 2 & 2 & 70 \\
\hline 6 & Kec. Batealin & 38 & 18 & 56 & 4 & 14 & 18 & 1 & 4 & 5 & 1 & 2 & 3 & 82 \\
\hline 7 & Kec. Tahunan & 42 & 17 & 59 & 1 & 14 & 15 & 1 & 7 & 8 & 0 & 5 & 5 & 87 \\
\hline 8 & Kec. Jepara & 36 & 12 & 48 & 6 & 7 & 13 & 1 & 5 & 6 & 3 & 3 & 6 & 73 \\
\hline 9 & Kec. Mlongpo & 35 & 16 & 51 & 1 & 12 & 13 & 1 & 4 & 5 & 0 & 3 & 3 & 72 \\
\hline 10 & Kec. Bangsi & 37 & 25 & 62 & 2 & 19 & 21 & 1 & 9 & 10 & 1 & 7 & 8 & 101 \\
\hline 11 & Kes. Keling & 36 & 22 & 58 & 3 & 13 & 16 & 1 & 1 & 2 & 0 & 3 & 3 & 79 \\
\hline 12 & Kec. Karimunjawa & 14 & 0 & 14 & 2 & 1 & 3 & 0 & 1 & 1 & 1 & 0 & 1 & 19 \\
\hline 13 & Kec. Kalinysmatan & 36 & 6 & 42 & 2 & 7 & 9 & 0 & 5 & 5 & 1 & 1 & 2 & 58 \\
\hline 14 & Kec. Kembang & 43 & 13 & 56 & 4 & 8 & 12 & 1 & 3 & 4 & 0 & 1 & 1 & 73 \\
\hline 15 & Kec. Denorojo & 31 & 19 & so & 2 & 11 & 13 & 1 & 7 & 8 & 0 & 2 & 2 & 73 \\
\hline 16 & Kec. Pabis All & 27 & 12 & 39 & 2 & 7 & 9 & 0 & 3 & 3 & 1 & 2 & 3 & 54 \\
\hline
\end{tabular}

Gambar 1. Jumlah satuan pendidikan di Kabupaten Jepara (Sumber: Referensi.data.kemdikbud.go.id)

Berdasarkan Gambar 1, Kecamatan Donorojo memiliki jumlah satuan pendidikan sebanyak 73 satuan pendidikan termasuk di dalamnya adalah Desa Bandungharjo merupakan desa yang berada di Kecamatan Donorojo Kabupaten Jepara Jawa Tengah. Desa Bandungharjo terletak di sebelah ujung Utara dan berjarak $\pm 43 \mathrm{Km}$ dari pusat Kota Jepara, dengan kondisi jalan yang berkelok-kelok. Desa Bandungharjo ini merupakan desa yang kecil, akan tetapi terdapat banyak lembaga pendidikan, seperti PAUD, TK, SD/MI, MTs, dan MA/SMK. Salah satu sekolah yang ada di Desa Bandungharjo yaitu MTs SA PP Roudlotut Tholibin. MTs Satu Atap (SA) Pondok Pesantren (PP) Roudlotut Tholibin terletak di Jl. Raya Bandungharjo Dukuh Tengger RT.03 RW.01 Kecamatan Donorojo Kabupaten Jepara.

MTs SA PP Roudlotut Tholibin merupakan sekolah berbasis pesantren, dimana $80 \%$ siswanya yang bersekolah di MTs SA PP Roudlotut Tholibin tinggal di pondok pesantren. Gedung MTs SA PP Roudlotut Tholibin satu atap dengan Pondok Pesantren dan MA SA PP Roudlotut Tholibin. Fasilitas di MTs SA PP Roudlotut Tholibin juga kurang memadai. Keterbatasan fasilitas ini seperti kurangnya guru dalam pemanfaatan teknologi sebagai media pembelajaran daring di musim pandemi COVID-19. 
ABDIMAS: Jurnal Pengabdian Masyarakat Universitas Merdeka Malang Volume 6, No. 4, November 2021: 478-490

Berdasarkan hasil wawancara dengan Kepala Sekolah, mengatakan bahwa guru kurang menggunakan media pembelajaran berbasis teknologi saat kegiatan pembelajaran secara daring di musim pandemi COVID-19 dan juga guru masih menggunakan pembelajaran yang konvensional. Sementara itu, hasil wawancara dengan salah satu guru di MTs SA PP Roudlotut Tholibin menyebutkan bahwa guru belum menggunakan teknologi informasi untuk proses pembelajaran online, dan guru belum menguasai teknologi yang sedang berkembang, serta guru masih kesulitan memanfaatkan media pembelajaran berbasis teknologi. Proses pembelajaran yang masih bersifat konvensional membuat peserta didik merasa jenuh dan pemahaman materi belum maksimal. Dengan media pembelajaran berbasis teknologi yang masih jarang digunakan oleh guru dan kurangnya kemampuan guru dalam membuat media pembelajaran berbasis teknologi berdampak pada rendahnya minat belajar siswa dimusim pandemi COVID-19.

Learning from home atau Belajar dari Rumah (BDR) dilaksanakan dengan sistem Pembelajaran Jarak Jauh (PJJ). Dalam Undang-Undang Nomor 20 Tahun 2003 pasal 1 ayat 15 dijelaskan bahwa PJJ merupakan suatu proses pendidikan dimana peserta didik dipisahkan dari pendidik dan pembelajarannya menggunakan berbagai sumber belajar melalui teknologi komunikasi, informasi, dan media lainnya. Dalam praktiknya, pembelajaran dari rumah terbagi menjadi dua pendekatan yaitu pembelajaran jarak jauh online dan pembelajaran offline. Dalam melaksanakan pembelajaran dari rumah, satuan pendidikan dapat memilih pendekatan (online atau offline atau kombinasi keduanya) sesuai dengan karakteristik dan ketersediaan, kesiapan sarana dan prasarana di lembaganya.

Pembelajaran online adalah pembelajaran yang dilakukan tanpa melakukan tatap muka atau pembelajaran dilakukan secara online. Berdasarkan informasi yang disampaikan oleh pendidik ternyata siswa merasa bosan dan jenuh. Melihat kondisi tersebut maka pendidik harus mulai melakukan invasi terkait dengan media pembelajaran yang digunakan. Salah satu media interaktifyang dapat dimanfaatkan oleh guru dalam situasi pembelajaran online di masa pandemi adalah aplikasi kuis Kahoot (Elita \& Asrori, 2019). Aplikasi ini adalah berbentuk web-based yang bisa diakses dengan jaringan internet tanpa harus menginstallnya terlebih dahulu serta mampu memberikan gambaran tentang proses pembelajaran yang dapat dievaluasi secara langsung, dimana Pendidikan bisa langsung membuat soal didalamnya dan peserta didik juga bisa langsung bergabung dan mengerjakan soal evaluasi yang dibuat oleh pendidik.

Ilustrasi yang lain terkait proses pembelajaran adalah ketidaksiapan guru dan siswa untuk pembelajaran online juga menjadi masalah. Pergeseran sistem pembelajaran konvensional ke sistem online secara tiba-tiba akibat pandemi COVID-19 dan tanpa persiapan yang matang dapat mengakibatkan proses pembelajaran kurang efektif. Akhirnya, beberapa guru tidak dapat mengikuti perubahan dengan pembelajaran berbasis informasi dan teknologi. Para guru tidak bisa menghindari penggunaan teknologi untuk mendukung pembelajaran yang dilakukannya terutama pada saat pandemi COVID-19. Maka dari itu, semua ini harus dilakukan supaya proses pembelajaran dapat berjalan dan terpenuhi hak-hak peserta didik dalam memperoleh pendidikan bahkan dalam kondisi pandemi COVID-19.

Selain itu, melihat kondisi sekarang di masyarakat, sebagian orang tua peserta didik tidak memiliki perangkat handphone (android) atau komputer untuk mendukung pembelajaran online khususnya bagi siswa sendiri. Kondisi tersebut membuat mereka bingung menghadapi fakta yang ada terkait dengan 
sistem pembelajaran yang ada. Di satu sisi satuan pendidikan dihadapkan pada minimnya fasilitas penunjang, di sisi lain ada tuntutan pemenuhan layanan pendidikan bagi peserta didik. Sesuai dengan amanat UUD 1945 Pasal 31 Ayat (1) disebutkan bahwa setiap warga negara berhak atas pendidikan. Ketersediaan fasilitas pada pembelajaran online terhambat banyak masalah, seperti belum adanya kuota (pulsa) yang membutuhkan biaya cukup tinggi, para orang tua siswa dari kalangan ekonomi menengah ke bawah tidak punya anggaran untuk menyediakan jaringan internet. Jaringan internet walaupun sudah ada, para siswa mengalami kesulitan dalam mengakses jaringan internet yang disebabkan tempat tinggal mereka berada di pedesaan terpencil atau daerah tertinggal. Jadi walaupun ada sebagian siswa menggunakan jaringan seluler, tetapi jaringannya tidak stabil, yang dikarenakan letak geografis yang masih jauh dari jangkauan sinyal seluler. Hal ini juga menjadi masalah yang banyak terjadi pada siswa yang mengikuti pembelajaran online, sehingga pelaksanaannya kurang efektif.

Menurut hasil penelitian yang dilakukan Asmuni (2020), penerapan pembelajaran online atau pembelajaran jarak jauh pada saat pandemi COVID-19 mengalami berbagai kendala yang dialami oleh guru, siswa, dan orang tua. Beberapa masalah yang muncul dalam pembelajaran jarak jauh, yaitu penguasaan IT oleh guru yang lemah, keterbatasan pengawasan terhadap siswa, ketidakaktifan siswa dalam mengikuti pembelajaran, terbatasnya fasilitas penunjang dan akses jaringan internet, dan keterbatasan orang tua dalam mendampingi anak-anaknya selama pembelajaran online. Berbagai permasalahan tersebut dapat diatasi dengan peningkatan kompetensi penguasaan $\mathrm{Tl}$, pengawasan intensif yang melibatkan peran orang tua, dan pemberian tugas manual (Asmuni, 2020).

Media pembelajaran merupakan sarana atau instrumen yang mendorong efektivitas dan efisiensi kegiatan pembelajaran, terutama pembelajaran dari rumah pada saat terjadi pandemi virus COVID19 (Mualim \& Saputra, 2021; Haryadi et al., 2019). Oleh karena itu, penggunaan media pembelajaran yang adaptif dan berkualitas merupakan salah satu cara untuk menciptakan suasana belajar yang menyenangkan dan meningkatkan hasil belajar siswa (Sumarlin, 2021; Batubara \& Ariani, 2019; Sulasmono \& Dwikurnaningsih, 2012).

Pemilihan dan penggunaan media pembelajaran adaptif untuk mendukung pembelajaran online antara lain dapat dilakukan dengan mempertimbangkan model SECTION yang ditawarkan oleh Bates (2019), yaitu S-tudent (siswa), E-ase of use (easy to use), C-ost (biaya atau waktu), T-eaching (kegiatan belajar), I-nteraksi (interaksi), masalah O-rganisasi (manajemen masalah), $\mathrm{N}$-etworking (memperluas jaringan), dan S-keamanan dan privasi (keamanan dan privasi).

Salah satu media interaktif yang dapat dimanfaatkan oleh guru dalam situasi pembelajaran online di masa pandemi ini adalah aplikasi Kahoot (Rahim et al., 2020; Elita \& Asrori, 2019). Kahoot merupakan salah satu alternatif dari media pembelajaran yang membuat proses pembelajaran luring maupun daring menjadi lebih menarik dan tidak membosankan bagi peserta didik. Pembelajaran menggunakan aplikasi Kahoot memerlukan media komputer maupun android serta jaringan internet yang stabil. Pembelajaran dengan menggunakan media komputer dapat menumbuhkan semangat peserta didik untuk mengerjakan soal yang ada. Hal ini disebabkan karena adanya tampilan warna serta gambar yang membuatnya menjadi lebih nyata. Kahoot memiliki tampilan yang menarik yang mampu meningkatkan 
ABDIMAS: Jurnal Pengabdian Masyarakat Universitas Merdeka Malang Volume 6, No. 4, November 2021: 478-490

minat peserta didik serta meningkatkan partisipasi aktif peserta didik dengan teman sesamanya dengan cara kompetitif terhadap pembelajaran yang sedang mereka pelajari (Ishak, 2017).

Mengingat keterbatasan sarana dan prasarana yang ada maka pendidik harus mampu mengoptimalkan media pembelajaran yang kreatif dan inovatif. Karena maka model pembelajaran dalam jaringan (daring) merupakan model pembelajaran tanpa tatap muka secara langsung antar pendidik dan peserta didik, melainkan secara online yang menggunakan jaringan teknologi internet. Pendidik harus mampu menggunakan dan memilih media yang tepat sehingga mampu dijangkau oleh peserta didik dan mampu dilaksanakan oleh pendidik. Di dalam sistem pembelajaran daring pendidik dan peserta didik melakukan pembelajaran bersama, waktu yang sama, dengan menggunakan berbagai macam aplikasi komputer maupun smartphone yang dapat digunakan untuk mengakses aplikasi yang digunakan untuk proses pembelajaran seperti WhatsApp, Telegram, Zoom Meeting, Google Meet, Google Classroom, Quiepper School, Ruang Guru dan berbagai macam aplikasi lainnya.

Solusi pembelajaran yang dapat dilaksanakan adalah pembelajaran daring merupakan solusi alternatif pelaksanaan pembelajaran di masa pandemi COVID-19, meskipun memunculkan sejumlah permasalahan dalam penerapannya baik bagi guru, peserta didik, orang tua, maupun institusi pendidikan. Maka dalam kegiatan pengabdian ini permasalahan mitra yang dibahas adalah model pembelajaran daring dan media yang dapat digunakan untuk proses pembelajaran tersebut. Sedangkan solusi untuk menyelesaikan masalah tersebut adalah dengan mencari media yang tepat/sesuai dengan kondisi di wilayah tersebut kemudian diimplementasikan.

Berdasarkan latar belakang tersebut, lembaga pendidikan khususnya guru, peserta didik, orang tua, maupun institusi pendidikan perlu memahami jenis media yang dapat digunakan untuk melaksanakan pembelajaran daring. Diharapkan pemahaman terhadap jenis media yang dapat digunakan untuk pembelajaran daring dapat diimplementasikan untuk meningkatkan kualitas pembelajaran yang selama ini dilaksanakan. Perlunya pelatihan dalam penggunakan berbagai macam media seperti Google Classroom, video Youtube, Power Point, WhatsApp, Telegram, Kahoot bertujuan untuk memberikan pengalaman bagi pendidik, peserta didik, pengelola lembaga pendidikan dalam menjalankan proses pembelajaran secara professional. Dengan adanya program pengabdian ini diharapkan para pendidik mengenal dan memahami serta menggunakan beragam aplikasi yang bisa mensuport program pembelajaran secara online.

\section{METODE}

Kegiatan dilaksanakan di Desa Bandungharjo Kecamatan Donorojo Kabupaten Jepara Provinsi Jawa Tengah dengan lokasi pada Yayasan PP Roudlotut Tholibin Bandungharjo dengan melibatkan seluruh pendidik yang tergabung pada yayasan tersebut dan lembaga pendidikan sekitar. Berdasarkan wawancara sebelum pelaksanaan kegiatan diperoleh informasi bahwa para pendidik membutuhkan wawasan dan pemahaman teknologi yang mendukung kegiatan belajar mengajar secara daring.

Metode pelaksanaan program dilakukan secara bertahap dengan sasaran kegiatan pengabdian masyarakat ini adalah para pendidik di Desa Bandungharjo. Program yang dilakukan yaitu berupa 
pelatihan dan pendampingan pembuatan media pembelajaran yang inovatif di masa pandemi COVID19 dengan memanfaatkan teknologi berbasis komputer yang ada. Adapun langkah-langkah yang digunakan dalam metode pelaksanaan pengabdian kepada masyarakat digambarkan pada Gambar 2.

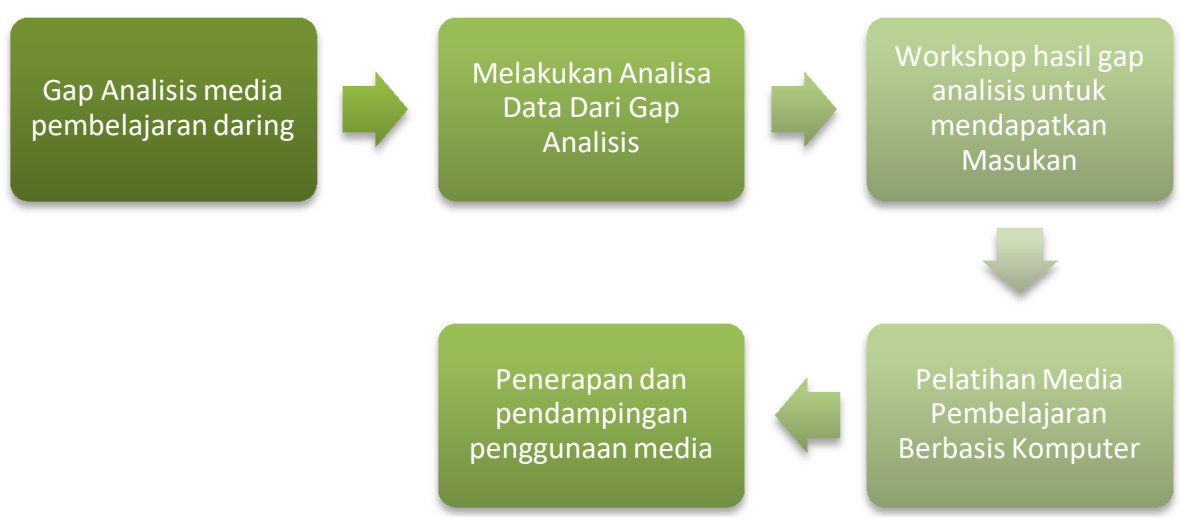

Gambar 2. Alur kegiatan pengabdian pengembangan media pembelajaran

Berdasarkan gambar 2 maka tahapan dalam proses pelaksanaan pengabdian ini dilakukan dengan beberapa tahap diantaranya: (1) Gap analisis media pembelajaran, kegiatan ini bertujuan untuk mengetahui kelemahan dan kelebihan media pembelajaran yang digunakan mitra serta perspektif masa depan yang ingin dicapai mitra; (2) Analisis data dari hasil gap analisis yang telah dilakukan, kegiatan ini bertujuan untuk mengetahui kondisi permasalahan-permasalahan yang dihadapi mitra; (3) Workshop hasil gap analisis, workshop ini bertujuan sebagai bahan perancangan model media pembelajaran yang dibuat bahan pelatihan kepada mitra sesuai dengan kondisi mitra dan arah perkembangan sekolah di masa depan; (4) Pelatihan media pembelajaran berbasis komputer, kegiatan ini bertujuan untuk memberikan pemahaman dan ragam media yang dapat digunakan untuk proses pembelajaran beserta penggunaannya oleh mitra; (5) Penerapan dan pendampingan dalam menggunakan media yang telah dipelajari dan dilatih di tempat mitra.

\section{HASIL DAN PEMBAHASAN}

\section{Hasil}

Kegiatan pengabdian masyarakat dilaksanakan di MTs Satu Atap (SA) Pondok Pesantren (PP) Roudlotut Tholibin, dengan program sebagai berikut: (1) Kegiatan survei awal dan persiapan pelaksanaan pengabdian masyarakat; (2) Analisis kesenjangan media pembelajaran online; (3) Pelatihan pembuatan media pembelajaran berbasis teknologi komputer; dan (4) Penerapan dan penggunaan media pembelajaran berbasis teknologi komputer. 
ABDIMAS: Jurnal Pengabdian Masyarakat Universitas Merdeka Malang Volume 6, No. 4, November 2021: 478-490

\section{Kegiatan survei awal dan persiapan pelaksanaan pengabdian masyarakat dan gap analysis}

Kegiatan survei awal sekaligus penyusunan analisis GAP media pembelajaran online di mitra. Pertemuan awal dengan pengurus dan guru MTs Satu Atap (SA) Pondok Pesantren (PP) Roudlotut Tholibin yang diwakili oleh Kepala Sekolah (Gambar 3). Sebelum kegiatan dilaksanakan, tim pengabdian harus menyusun konsep yang telah disepakati dan kemudian menyampaikannya kepada mitra kerja untuk masukan.
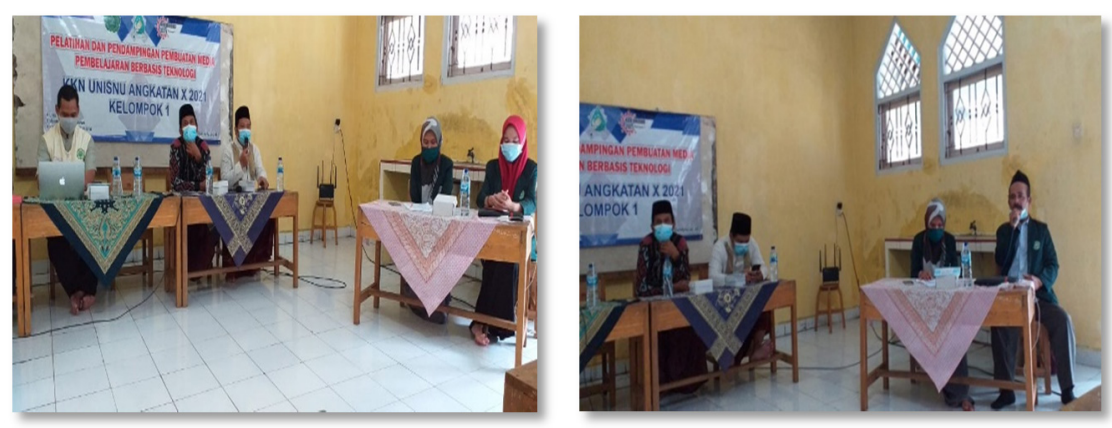

Gambar 3. Kegiatan workshop awal dengan MTs SA PP Roudlotut Tholibin

\section{Workshop hasil gap analisis untuk mendapatkan masukan}

Kegiatan workshop hasil menjadi sangat penting dilakukan karena untuk pelaksanaan kegiatan selanjutnya. Dalam workshop ini adalah untuk memastikan bahwa rencana kegiatan yang nanti dilaksanakan sesuai dengan hasil observasi awal dan komunikasi penggalian solusi yang telah disepakati. Dengan adanya workshop ini pengabdi mendapatkan masukkan dari para stakeholder dan guru terkait jenis pelatihan yang akan dilakukan. Hasil dari workshop untuk memperoleh masukan menyepakati materi pelatihan yang akan dilaksanakan yaitu: (1) Menyusun RPP daring, luring, dan kombinasi; (2) Menyusun bahan ajar sesuai dengan RPP; (3) Membuat media pembelajaran dengan Microsoft Power Point sesuai dengan bahan ajar; dan (5) Membuat evaluasi pembelajaran dengan aplikasi Kahoot.

Semua kegiatan pelatihan adalah dalam rangka meningkatkan kompetensi dari pendidik dalam melaksanakan tugas dan tanggungjawabnya secara profesional. Kompetensi guru adalah kemampuan seorang guru dalam penguasaan pengetahuan, keterampilan, nilai, dan sikap dalam menjalankan tugas dan tanggungjawab sebagai seorang pendidik. Seorang guru juga akan mampu melaksanakan tugasnya dengan baik apabila memiliki kemampuan sesuai dengan bidang keahliannya.

Selain harus selalu meningkatkan kompetensi, guru juga dituntut untuk dapat menciptakan lingkungan belajar yang efektif dan menyenangkan sehingga dapat menjadikan mutu pendidikan menjadi lebih baik. Oleh karena itu, kompetensi guru juga sangat berpengaruh terhadap hasil belajar siswa.

Dari hasil workshop pada Gambar 4 yang telah dilakukan, dengan dihadiri dari tim pengabdi dan guru di lingkungan Yayasan satuan Pendidikan maka pertemuan tersebut telah menghasilkan rancangan pelatahinan yang dilakukan seperti yang telah disepakati dan masukan bersama selanjutnya adalah kegiatan pelatihan. 

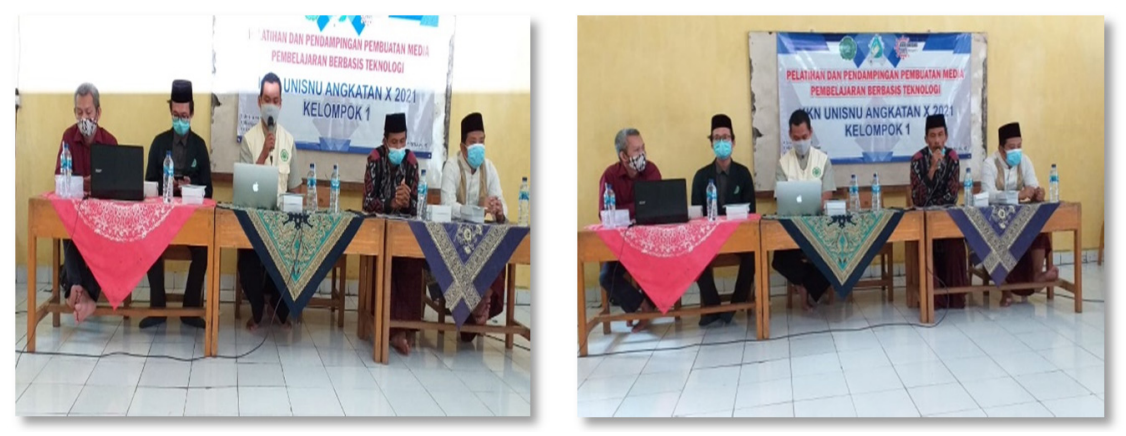

Gambar 4. Kegiatan FGD dengan Guru MTs SA PP Roudlotut Tholibin

\section{Pelatihan pembuatan media pembelajaran berbasis komputer}

Pelatihan dilakukan dalam rangka memberikan pemahaman atau menambah pengetahuan dan keterampilan peserta diklat. Peraturan Pemerintah (PP) Nomor 19 Tahun 2005 Pasal 28 menyebutkan bahwa selain memenuhi kualifikasi tertentu, tenaga pengajar harus memiliki empat jenis kompetensi, yaitu kompetensi pedagogik, kompetensi kepribadian, kompetensi profesional, dan kompetensi sosial. Keempat jenis kompetensi tersebut merupakan kompetensi minimal yang harus dimiliki setiap pendidik, mulai dari guru pada jenjang Pendidikan Anak Usia Dini (PAUD) hingga guru besar padajenjang perguruan tinggi. Kementerian Agama melalui Peraturan Menteri Agama Nomor 211 Tahun 2011 memperluas jenis kompetensi yang perlu dikuasai pendidik menjadi 6 jenis, dengan penambahan kompetensi spiritual dan kompetensi kepemimpinan.

Maka kompetensi tenaga pendidik tidak cukup hanya berupa kemampuan membuat perencanaan, silabus, pelaksanaan, dan evaluasi pembelajaran. Situasi saat ini mengharuskan guru meningkatkan kompetensi pedagogik mereka secara cepat hingga mencakup penguasaan dan penggunaan teknologi komunikasi dan informasi untuk mendukung pembelajaran virtual atau berbasis daring. Termasuk di dalam penguatan kompetensi ini adalah peningkatan kemampuan guru untuk mengemas dan menyajikan konten pembelajaran dalam bentuk naratif-audio-visual yang menarik perhatian dan mudah dipahami peserta didik. Untuk itu kegiatan pelatihan sesuai Gambar 5 yang pertama adalah terkait dengan media pembelajaran dengan beberapa sub materi mulai dari perangkat pembelajaran sampai dengan media pembelajaran.
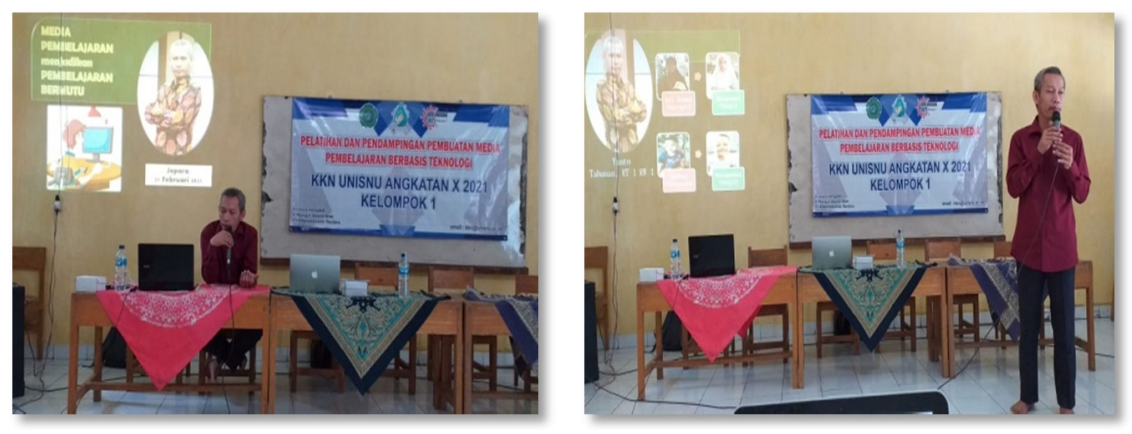

Gambar 5. Kegiatan pelatihan media pembelajaran 
ABDIMAS: Jurnal Pengabdian Masyarakat Universitas Merdeka Malang Volume 6, No. 4, November 2021: 478-490

Materi pelatihan pada kegiatan pelatihan selanjutnya sesuai Gambar 6 adalah membuat konten media pembelajaran dengan menggunakan Microsoft Power Point. Kegiatan ini sangat penting karena media untuk membuat sebuat konten yang cukup fleksibel adalah dengan aplikasi Power Point, dengan aplikasi ini pendidik dapat menyajikan informasi terkait dengan materia pembelajaran dengan menarik bahkan dapat dibuat sebagai video dengan mudah.
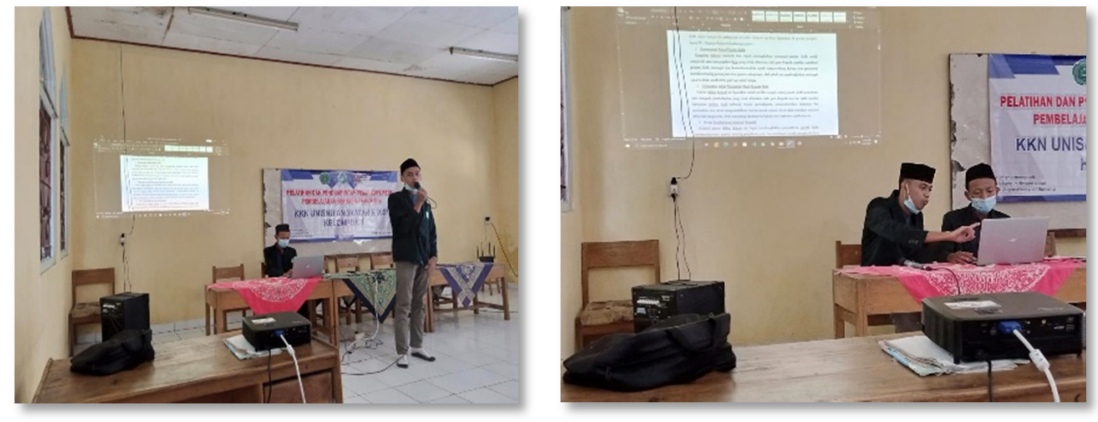

Gambar 6. Pelatihan penggunaan Power Point sebagai media pembelajaran yang kreatif

Kegiatan pelatihan yang terakhir yang dilakukan oleh tim pengabdi bersama dengan mitra MTs SA PP Roudlotut Tholibin adalah memahami dan membuat media evaluasi yang menarik dan inovatif. Media yang dipelajari berikutnya adalah menggunakan aplikasi Kahoot untuk melaksanakan proses evaluasi pembelajaran. Kahoot merupakan situs untuk membuat pembelajaran online yang menghadirkan suasana pembelajaran menjadi lebih menarik. Di situs ini para guru bisa membuat berbagai pertanyaan mengenai materi pelajaran dan peserta didik dapat menjawab pertanyaan tersebut. Kahoot ini bisa digunakan di ponsel maupun laptop/PC dapat dicontohkan tampilan pada PC sesuai dengan Gambar 7.
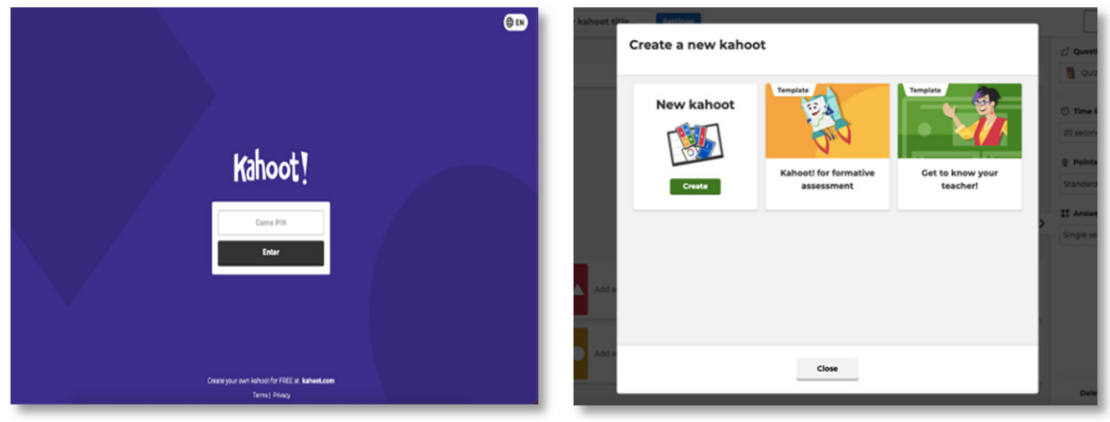

Gambar 7. Tampilan Kahoot

Tampilan Kahoot yang menarik dan dapat meningkatkan semangat siswa untuk menjawab atau mengerjakan kuis yang telah diberikan oleh guru, membuat siswa bersemangat dan berlomba-lomba menjawabnya, karena keingintahuannya terhadap soal atau permainan selanjutnya. Manfaat kahoot yaitu dapat menginspirasi siswa untuk lebih aktif dalam belajar. Selain itu, kahoot berguna untuk melihat sejauh 
mana siswa memahami dan memahami pembelajaran yang telah diberikan oleh guru kepada mereka, serta dapat digunakan untuk melihat kemajuan siswa mencapai tujuan pembelajaran, mengidentifikasi kekuatan dan kelemahan, mengidentifikasi siswa mendapatkan manfaat lebih dari sekadar mengajar. Melalui permainan dalam Kahoot ini dapat menambah pengetahuan siswa, memotivasi reaksi siswa terhadap penjelasan guru, dan membantu siswa mengkonkritkan sesuatu yang abstrak dan lain sebagainya. Peserta pelatihan dan pendampingan media pembelajaran menggunakan aplikasi dapat disajikan sesuai Gambar 8.
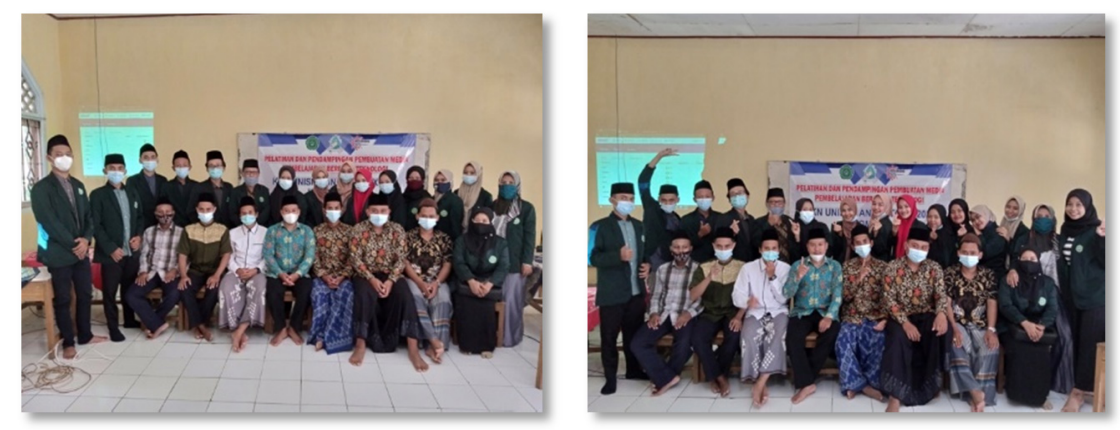

Gambar 8. Peserta pelatihan media pembelajaran dengan aplikasi Kahoot

\section{Penerapan dan pendampingan penggunaan media pembelajaran berbasis teknologi}

Pendampingan dilakukan untuk memastikan mitra dapat mengaplikasikan media yang terlatih dengan baik, kegiatan pendampingan sesuai dengan yang disajikan pada Gambar 9. Dengan pelaksanaan pendampingan ini, pendidik merasa terbantu dalam melaksanakan program pembelajaran pada saat pandemi. Pendidik merasa dengan pemanfaatan teknologi yang ada dan berkembang di masyarakat saat ini bukan tidak mungkin pembelajaran online dapat terlaksana dengan baik. Pembuatan media interaktif dapat membantu siswa memahami materi yang disampaikan oleh guru. Sehingga kompetensi pendidik dalam berinovasi dan berkreasi dalam membuat media pembelajaran sangat dibutuhkan pada saat pandemi dengan sistem pembelajaran online (Nursafitri et al., 2021; Safitri \& Nugraha, 2021).
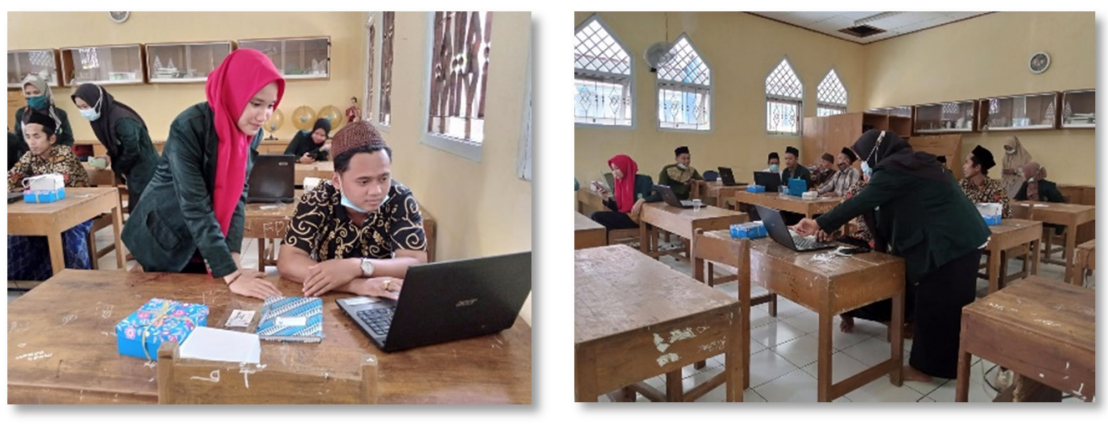

Gambar 9. Pendampingan penggunaan media pembelajaran daring 
ABDIMAS: Jurnal Pengabdian Masyarakat Universitas Merdeka Malang

Volume 6, No. 4, November 2021: 478-490

\section{Pembahasan}

Hasil kegiatan program pelatihan dan pendampingan serta monitoring yang dilakukan oleh tim pengabdian dengan mitra diketahui bahwa dari 17 peserta yang mengikuti program pelatihan pembuatan media pembelajaran berbasis teknologi komputer telah memperoleh pengetahuan dan pemahaman serta menerapkan keterampilan yang diperoleh selama pelatihan di MTs. SA PP Roudlotut Tholibin. Materi yang diimplementasikan adalah pembuatan bahan ajar menggunakan Power Point dan membuat media evaluasi dengan menggunakan aplikasi Kahoot. Sejumlah 17 peserta yang menjadi mitra kegiatan telah berupaya mengembangkan media pembelajaran yang kreatif dan inovatif sesuai dengan hasil yang didapat dalam kegiatan pelatihan dan pendampingan. Karena kebijakan Belajar dari Rumah (BDR) yang diberlakukan di masa pandemi ini mendorong para pendidik untuk terus berinovasi dan berkreasi dalam mentransfer penagetahuan kepada anak didiknya. Kegiatan selanjutnya yang direncanakan oleh tim pengabdian bersama mitra adalah program kegiatan peningkatan kompetensi keterampilan optimalisasi penggunaan media Kahoot untuk proses evaluasi dalam kegiatan pembelajaran. Dampak pelaksanaan program yang dilakukan pada mitra pengabdian ini dapat dilihat pada Tabel 1.

Tabel 1. Dampak pelaksanaan program pelatihan

\begin{tabular}{|c|c|}
\hline Detail Kegiatan & Dampak Bagi Peserta \\
\hline $\begin{array}{l}\text { Pre-test } \\
\text { Workshop gap analisis media pembe- } \\
\text { lajaran }\end{array}$ & $\begin{array}{l}\text { Pendataan potensi wawasan media pembelajaran dari mitra peserta. } \\
\text { Antusiasme dan komitmen peserta mengikuti sesi pelatihan berikutnya }\end{array}$ \\
\hline $\begin{array}{l}\text { Pelatihan pembuatan media pembe- } \\
\text { lajaran berbasis komputer }\end{array}$ & $\begin{array}{l}\text { Peningkatan wawasan peserta terhadap fitur yang tersedia di aplikasi } \\
\text { Power Point untuk pembuatan video }\end{array}$ \\
\hline $\begin{array}{l}\text { Pelatihan pembuatan media pembe- } \\
\text { lajaran berbasis komputer }\end{array}$ & $\begin{array}{l}\text { Peningkatan keterampilan peserta dalam menggunakan aplikasi Kahoot } \\
\text { sebagai salah satu media untuk evaluasi proses pembelajaran }\end{array}$ \\
\hline $\begin{array}{l}\text { Post-test } \\
\text { Pendampingan dan monitoring }\end{array}$ & $\begin{array}{l}\text { Peningkatan kompetensi dan keterampilan peserta dalam meng- } \\
\text { kreasikan slide pembelajaran dengan aplikasi Power Point. } \\
\text { Setiap peserta menghasilkan satu media kreatif dan inovatif tentang } \\
\text { materi pembekajaran yang diampu masing-masing. } \\
\text { Peningkatan pengetahuan dan wawasan peserta pengabdian terhadap } \\
\text { kebutuhan dan pengembangan media pembelajaran }\end{array}$ \\
\hline
\end{tabular}

Berdasarkan Tabel 1 bahwa program kegiatan ini memiliki beberapa dampak di antaranya adalah bertambahnya wawasan mitra terkait dengan inovasi teknologi pembelajaran. Selain itu, peserta secara antusias mengikuti kegiatan sehingga banya informasi dan keterampilan yang didapat. Dengan output program ini peserta sudah memiliki media pembelajaran yang dapat digunakan untuk transfer pengetahuan kepada peserta didik, minimal ada perubahan dari media yang biasa digunakan sehari-hari dalam proses pembelajaran.

\section{SIMPULAN DAN SARAN}

Dari hasil pelaksanaan pengabdian kepada masyarakat yang telah dilaksanakan dapat ditarik kesimpulan, sebagai berikut: (1) Seluruh tahapan program pengabdian masyarakat meliputi perencanaan, 
pelatihan serta pendampingan, dan monitoring telah dilaksanakan dengan baik pada mitra; (2) Para pendidik mendapatkan pengalaman terkait dengan jenis-jenis media pembelajaran yang dapat digunakan untuk kegiatan proses pembelajaran di masa pandemi; (3) Peserta mampu membuat media pembelajaran berbasis Microsoft Power Point yang menarik dengan konten yang interaktif. Serta mampu menggunakan aplikasi Kahoot sebagai sarana media evaluasi dalam proses pembelajaran berbasis webbased.

Pelaksanaan pembelajaran daring yang merupakan pembelajaran jarak jauh di masa pandemi COVID-19 memiliki beragam problematika yang dialami guru, peserta didik, dan orang tua. Permasalahan dari guru berupa lemahnya penguasaan IT dan terbatasnya akses pengawasan peserta didik, dari peserta didik berupa kekurangaktifan mengikuti pembelajaran, keterbatasan fasilitas pendukung dan akses jaringan internet, sementara dari orang tua berupa keterbatasan waktu dalam mendampingi anaknya di saat pembelajaran daring. Beragam permasalahan tersebut dapat diatasi dengan meningkatkan kompetensi penguasaan IT, pengawasan intensif dengan melibatkan peran orang tua, dan memberikan penugasan secara manual. Berdasarkan pada hasil kesimpulan, maka dapat diberikan saran atas apa yang telah dicapai melalui program pengabdian kepada masyarakat ini, agar dapat dikembangkan lebih baik lagi. Pertama, pembelajaran daring di saat pandemi COVID-19 pendidik harus mencari solusi dan terobosan yang inovatif dan berpikir secara kreatif agar proses kegiatan pembelajaran di sekolah tetap berjalan walaupun tidak dapat bertatap muka langsung. Kedua, pengabdian selanjutnya tidak hanya terkait dengan pembuatan media pembelajaran daring akan tetapi juga ditingkatkan pada penilaian kinerja pendidik selama proses pembelajaran daring terkait dengan media yang digunakan oleh guru, bentuk media serta perangkat pembelajaran lainnya.

\section{UCAPAN TERIMAKASIH}

Program pengabdian masyarakat yang dilaksanakan merupakan skema layanan Kuliah Kerja Nyata Program Pemberdayaan Masyarakat (KKN-PPM). Dengan selesainya program kami tim layanan ingin mengucapkan terima kasih: (1) Lembaga Penelitian dan Pengabdian kepada Masyarakat (LPPM) Universitas Islam Nahdlatul Ulama (UNISNU) Jepara yang telah mengkoordinasikan pelaksanaan kegiatan pengabdian kepada masyarakat; (2) Kepala Sekolah MTs Desa Bandungharjo. SA PP Roudlotut Tholibin sebagai mitra program dalam pelaksanaan program KKN-PPM, dan telah aktif mengikuti program pengabdian kepada masyarakat.

\section{DAFTAR PUSTAKA}

Asmuni, A. (2020). Problematika pembelajaran daring di masa pandemi COVID-19 dan solusi pemecahannya. Jurnal Paedagogy, 7(4), 281-288. https://doi.org/10.33394/jp.v7i4.2941

Bates, A. W. (2019). Teaching in a digital age. Second Edition. Tony Bates Associates Ltd.

Batubara, H. H., \& Ariani, D. N. (2019). Model pengembangan media pembelajaran adaptif di Sekolah Dasar. Muallimuna: Jurnal Madrasah Ibtidaiyah, 5(1), 33-46.

https://10.31602/muallimuna.v5i1.2356 
ABDIMAS: Jurnal Pengabdian Masyarakat Universitas Merdeka Malang Volume 6, No. 4, November 2021: 478-490

Elita, V., \& Asrori, M. A. R. (2019). Pemanfaatan digital game base learning dengan media Aplikasi Kahoot.It untuk peningkatan interaksi pembelajaran. INSPIRASI: Jurnal Ilmu-Ilmu Sosial, 16(2), $141-150$.

Haryadi, R., Vita, M., Utami, I. S., Ihsanudin, I., Setiani, Y., \& Suherman, A. (2019). Briquettes production as teaching aids physics for improving science process skills. Journal of Physics: Conference Series, 1157(32006).

Ishak, H. B., Nor, Z. M., \& Ahmad, A. (2017). Pembelajaran interaktif berasaskan aplikasi Kahoot dalam pengajaran abad ke-21. In Seminar Serantau. Kedah: Jabatan Pendidikan Khas Institut Pendidikan Guru Kampus Darulaman Jitra. Dipetik, 11(5), 2.

Kementerian Pendidikan dan Kebudayaan (Kemdikbud). (2020). Jumlah data satuan pendidikan (sekolah) per kabupaten/kota.

https://referensi.data.kemdikbud.go.id/index11.php?kode=032000\&level=2

Keputusan Menteri Pendidikan dan Kebudayaan Republik Indonesia Nomor 04/KB/2020 tentang Panduan Penyelenggaraan Pembelajaran pada Tahun Ajaran 2020/2021 dan Tahun Akademik 2020/2021 di Masa Pandemi Corona Virus Disease 2019 (COVID-19).

Mualim, R., \& Saputra, M. F. (2021). Optimizing online learning during COVID-19 pandemic in junior high school. Journal of Islamic Education Students (JIES), 1(1), 19-27. https://10.31958/jies.v1i1.3193

Nursafitri, L., Purwanti, E., \& Fitriyah (2021). Pelatihan video pembelajaran kreatif di era new normal bagi Guru PAUD di Kecamatan Tanjung Bintang, Lampung Selatan. Abdimas:Jurnal Pengabdian Masyarakat Universitas Merdeka Malang, 6(1), 35-42. https://doi.org/10.26905/abdimas.v6i1.4919

Peraturan Menteri Agama Republik Indonesia Nomor 211 Tahun 2011 Tentang Pedoman Pengembangan Standar Nasional Pendidikan Agama Islam pada Sekolah.

Peraturan Pemerintah (PP) Nomor 19 Tahun 2005 Pasal 28 tentang Standar Nasional Pendidikan.

Rahim, R., Rahman, M. A., \& Putri, E. E. (2020). Development of Kahoot application as learning media for online learning in the Covid-19 pandemic. Math Didactic: Jurnal Pendidikan Matematika, 6(3), 308-320. https://10.33654/math.v6i3.1111

Safitri, N., \& Nugraha, S. P. (2021). Online learning readiness, academic resilience, and subjective wellbeing of junior high school students during the COVID 19 pandemic. Journal of Educational, Health and Community Psychology, 10(3), 509. https://10.12928/jehcp.v10i3.21213

Sulasmono, B. S., \& Dwikurnaningsih, Y. (2012). Pengembangan Model Pembelajaran Adaptif, Kooperatif, Aktif dan Reflektif (PAKAR). Satya Widya, 28(1), 93.

https://doi.org/10.24246/j.sw.2012.v28.i1.p93-110

Sumarlin, S. (2021). Pengembangan media pembelajaran adaptif berbasis Fuzzy Expert System untuk meningkatkan prestasi belajar siswa. Belantika Pendidikan, 4(1), 37-43.

https://doi.org/10.47213/bp.v4i1.105 